\title{
Expressions of Semenogelin Gene in Male Syrian Hamsters according to Photoperiod
}

\author{
Tae Hong Kim¹, Hyeon Jeong Kim¹, Sung-Ho Lee², Yong-Pil Cheon, and 'Donchan Choi ${ }^{1}$ \\ ${ }^{1}$ Dept of Life Science, College of Environmental Sciences, Yong-In University, Yongin 17092, Korea \\ ${ }^{2}$ Dept. of Biotechnology, Sangmyung University, Seoul 03016, Korea \\ ${ }^{3}$ Div. of Developmental Biology and Physiology, Dept. of Biotechnology, Sungshin University, Seoul 02844, Korea
}

\begin{abstract}
The morphogenetically matured spermatozoa (sperm) are generated in the testes by the spermatogenesis. They travel male reproductive tract with many substances secreted from the accessory reproductive organs. One of the substances is the semenogelin (SEMG) released from the seminal vesicles that is involved in the post-testicular maturation. The expression of SEMG gene was investigated in seminal vesicle tissues of sexually matured and regressed male Syrian hamsters by reverse transcription polymerase chain reaction (RT-PCR). The SEMG gene was uniquely identified in the seminal vesicles of the matured Syrian hamsters and compared to the genes reported previously. But the expression of SEMG gene was not observed in reproductively and completely regressed testes of Syrian hamsters. These results indicate that the expressions of the SEMG gene are related to the reproductive capability in the male Syrian hamsters.
\end{abstract}

Key words : Semenogelin, Reproductive activity, Photoperiod, Male Syrian hamster

\section{INTRODUCTION}

The reproductive strategy is unique from animal to animal. The Syrian hamsters follow the germ cell-forming process like rat and mouse investigated widely. But their reproductive activities are entirely arrested and become infertile in the winter climate of temperate zone (Choi \& Lee, 2012; Choi, 2013). The seasonal changes of reproductive function have been well established to be regulated by photoperiod (Stetson \& Watson-Whitmyre, 1984; Stetson \& Watson-Whitmyre, 1986). Long photoperiod as in summer (LP, equal to or greater than 12.5 hours of lightings in a day) sustains large testes but short photoperiod of winter (SP, equal to or less than 12 hours of lightings in a day) reduces discernibly the size of testes. Thus spermatogenesis is vigorously developed in LP and ceased completely in SP (Choi \& Han, 2010; Choi \& Lee, 2012).

The natural changes of seasonal reproductive function in the hamsters can be recapitulated in the laboratory lighting regime (Stetson \& Watson-Whitmyre, 1984). When the sexually mature male hamsters are moved to SP, they lose reproductive activities in 8 full weeks, showing reduced testicular mass and no spermatozoa. If the length of lighting in a day is set to LP mimicking summer daylight, the sexual functions are obviously resumed and recovered to LP conditions.

The spermatozoa are produced in the testes from where the haploid spermatozoa begins to travel male reproductive

Manuscript received October 23, 2019, Received in revised form November 12, 2019, Accepted November 25 , 2019

$\dagger$ Corresponding Author : Donchan Choi, Dept. of Life Science, College of Environmental Sciences, Yong-In University, Yongin 17092, Korea. Tel: +8231-8020-2781, Fax: +82-31-8020-2886, E-mail: dcchoi@yongin.ac.kr

This is an Open Access article distributed under the terms of the Creative Commons Attribution Non-Commercial License (http:// creative-commons.org/licenses/by-nc/3.0) which permits unrestricted non-commercial use, distribution, and reproduction in any medium, provided the original work is properly cited. 
track. On the course of the journey they meet the substances secreted from male reproductive organs and obtain capacity to fertilize the eggs (Nixon et al., 2006; de Lamirande, 2007). In the post-testicular maturation process they are exposed to various substances secreting from the Sertoli cells, epididymis, vas deferens, seminal vesicle, and prostate cells. The surface membrane of the spermatozoa undergoes diverse modification during which they are protected from the threat of microorganisms and reconstructed to gain fertilization capacity (Cohen et al., 2001; Dacheux et al., 2003; Bourgeon et al., 2004; Jalkanen et al., 2006; Nixon et al., 2006; de Lamirande, 2007).

One of the accessory reproductive organs is the seminal vesicles (vesicular glands or seminal glands) that are a pair of simple tubular glands postero-inferior to the urinary bladder of mammals (Hendry et al., 2006; Vidigal et al., 2010). They secrete a significant proportion of the fluid that ultimately becomes semen. One of the components released from the seminal vesicles is the semenogelin (SEMG). It has been reported to bind to the epididymal protease inhibitor (EPPIN) that is synthesized and secreted from the Sertoli cells of the testes and epididymal epithelial cells (Sivashanmugam et al., 2003; Bian et al., 2009). The complex that the EPPIN anatomically produced in advance combines with SEMG (EPPIN-SEMG complex) protects the spermatozoa from the microbial attacks (Yenugu et al., 2004; de Lamirande, 2007). Further the complexes are degraded by prostate specific antigen (PSA) enzyme that results in the production of fragments of SEMG, contributing the lighter spermatozoa to increase the progressing motility in order to approach to the ovulated egg (O'Rand et al., 2006). On the other hand, there are other proteins clusterin and lactotransferrin bound to spermatozoa already coated with EPPIN (Paasch et al., 2011; Zhang et al., 2013). Such a function of SEMG is important to mammalian reproduction and evoluted phylogenetically. However, the informations in Syrian hamsters is very limited.

The ejaculated spermatozoa are veneered with SEMG and undergo a temporary retardation of forward motility, resulting in infertility (O'Rand et al., 2004; O'Rand et al., 2009; Mitra et al., 2010). The progressing motility is resumed at the time when the PSA works for the degradation of the complex. Persistent SEMG on the surface of spermatozoa draws the seminal hyperviscosity and infertility (Esfandiari et al., 2008; Emami et al., 2009; Du Plessis et al., 2013). Moreover, it was documented that the presence of SEMG and EPPIN increased the frequency of idiopathic male infertility in specific population of human, thus proposing utilization of them to identify human male infertility ( $\mathrm{Wu}$ et al., 2019). In in vivo fertilization, SEMGs inhibited ectopic capacitation before sperm reach the fertilization site and the number of total SEMG-unbound sperm was directly linked to the possibility of fertilization (Yamasaki et al., 2017).

The goal of the present work was to identify the SEMG gene, compare to genes reported in other rodents, and to correlate the SEMG gene with reproductive capability of male Syrian hamsters maintained in different photoperiod.

\section{MATERIALS AND METHODS}

\section{Mature Syrian hamsters and tissue sampling}

Male Syrian hamsters (Mesocricatus auratus) were used to identify the SEMG gene. They were housed in plastic cages under LP conditions of light and dark (lights of 14 h:darkness of $10 \mathrm{~h}$ ) with an ambient temperature of $22 \pm 1^{\circ} \mathrm{C}$. Reproductive activities of these hamsters in 8 weeks after birth are always active in the photoperiod. Spermatozoa were confirmed in the testis and the epididymis by the microscopic examination. The animals were fed with standard laboratory mouse chow and tap water ad libitum. Some of the reproductively mature Syrian hamsters were transferred to SP (lights of $10 \mathrm{~h}$ :darkness of $14 \mathrm{~h}$ ) and kept for 8 weeks during which their reproductive activity is entirely degenerated. The seminal vesicle tissues among the reproductive organs were extracted and immediately subjected to the reverse 
transcription polymerase chain reaction (RT-PCR). The condition of management of animals was approved by the Yongin University Institutional Animal Care and Use Committee (YUIACUC-2018-02).

\section{Expressions of SEMG gene}

The expressions of SEMG gene were examined in seminal vesicles of the hamsters who had active and inactive reproduction capacity by regulating the photoperiod.

\section{Testicular sperm observation}

The male Syrian hamsters were sacrificed by decapitation. Immediately the testes were excised and the suitable parts of them were immersed in the physiological saline. The tissues were cut many times with sterile scissors without delay. Following $1 \mathrm{~min}$ at room temperature, $1 \mathrm{~mL}$ of supernatant was transferred into microcentrifuge tube. The tube was spun at $14,000 \mathrm{rpm}$ for $1 \mathrm{~min}\left(\mathrm{Centrisart}^{\circledR} \mathrm{A}-14 \mathrm{C}\right.$, Sartorius, Germany). The supernatant was removed and 1 $\mathrm{mL}$ of saline was added to the tube. The pellet in the tube was dispersed by sucking and releasing of pipette. One drop of the suspension was fallen onto the slide glass and smeared uniformly. Then the slide glass was dried completely and absolute methanol was fully applied. After the entire dryness of the slide, specific staining solution was employed and dispersed. Ten minutes later, the extra staining solution was cleanly washed with flowing tap water. Then the presence of spermatozoa was observed by light microscope (Leica DM500, Leica Microsystems, Switzerland).

\section{Primers}

The SEMG gene of Syrian hamster has not been identified up to now. Thus primer sequences for SEMG gene of the animal were chosen from the Rattus norvegicus SEMG 1 mRNA sequence (NM_012710.2) and the Mus musculus seminal vesicle secretory protein 2 mRNA (NM_017390.4) in the NCBI Reference Sequences. Also the mRNA from the Chinese hamsters was referenced (predicted mRNA of
Cricetulus griseus SEMG I, NCBI Reference Sequence (XM_003504573.1). The primers selected were 5'-tggccaac aaaaatccct-3' for forward direction and 5'-ctgccectccetttgtaa aa-3' for reverse direction. The anticipated size was 302 bp. The primers have high homology in comparison to the sequences of mouse and rat. Glyceraldehydes-3-phosphate dehydrogenase (GAPDH) PCR was used as reference standard for RT-PCRs in the present study. The primers of GAPDH were 5'-aaatgacccttcattgacc-3' for forward and 5 '-ccttccacaatgccaaagtt-3' for reverse. The anticipated size was 420 bp. Sequence analyses were done by a commercial sequencing service company (Bioneer, Korea).

\section{Total RNA extraction}

Total RNAs were isolated from tissue samples using TRIzol $^{\mathbb{R}}$ Reagent (Invitrogen, USA) according to the manufacturer's protocol. That is, the small pieces of tissues (50-100mg) were excised and subjected to sonicate with 1 $\mathrm{mL}$ of TRIzol ${ }^{\circledR}$ Reagent (VCX130, Vibra Cell ${ }^{\mathrm{TM}}$, Sonics \& Materials Inc., USA). The samples were transferred to new microcentrifuge tubes and spun for $5 \mathrm{~min}$ at 12,000 $\mathrm{rpm}$ at $4^{\circ} \mathrm{C}$. The supernatant was moved into the new tubes and left for $5 \mathrm{~min}$ of incubation, allowing to permit complete dissociation of the nucleoprotein complex. 0.2 $\mathrm{mL}$ of chloroform was added and capped firmly the tubes. Following the incubation of 2-3 min, the tubes were spun for $15 \mathrm{~min}$ at $12,000 \mathrm{rpm}$ at $4^{\circ} \mathrm{C}$. The upper aqueous phase was transferred to the new tubes. Half $\mathrm{mL}$ of isopropanol was added and incubated for $10 \mathrm{~min}$. Then the tubes were spun for $10 \mathrm{~min} 12,000 \mathrm{rpm}$ at $4^{\circ} \mathrm{C}$. The supernatant was discarded and the pellets were resuspended in $1 \mathrm{~mL}$ of 75\% ethyl alcohol. After agitation, the samples were spun for $5 \mathrm{~min}$ at $7,500 \mathrm{rpm}$ at $4^{\circ} \mathrm{C}$. The supernatant was eliminated and the pellets were allowed to dry for at least 5 min. The pellet was solubilized with $20-50 \mu \mathrm{L}$ of RNasefree water. Quantitation of the RNA was measured by the absorbance at $260 \mathrm{~nm}$ that provides total nucleic acid content and $280 \mathrm{~nm}$ that determines purity of the RNA. 


\section{Reverse transcription-polymerase chain reaction (RT-PCR)}

The extracted RNAs were used in RT-PCR reactions carried out with Maxime ${ }^{\mathrm{TM}}$ RT PreMix and AccuPower PCR Premix (Bioneer, Korea) according to the manufacturer's instructions. Reverse transcription was primarily carried out to create complementary DNAs (cDNAs) representing cell-specific RNA populations. The proper amount (1 pg-1 $\mu \mathrm{g})$ of tRNA was transferred to clean microcentrifuge tubes and mixed with the following materials: DEPCtreated water, reverse transcription reaction buffer, oligo (dT)20 primer, dNTPS (dATP, dTTP, dCTP, dGTP), reverse transcriptase, and RNase inhibitor. The tubes were gently agitated and incubated at $42^{\circ} \mathrm{C}$ for $60-90 \mathrm{~min}$. In order to inactivate the reverse transcriptase the tubes were heated to $85^{\circ} \mathrm{C}$ for $5 \mathrm{~min}$. The cDNA products transcribed were stored at $-20^{\circ} \mathrm{C}$.

PCR was performed with the cDNA diluted with TE buffer (10 mM Tris (pH 8.0), $0.1 \mathrm{mM}$ EDTA). The microcentrifuge tubes with template cDNA (typically 10 ng) were mixed with water, 10× PCR Buffer, dNTP Mix, primers (forward and reverse), Taq DNA Polymerase, and $25 \mathrm{mM} \mathrm{MgCl}$. The tubes were stirred gently by vortexing and spun briefly to collect all components to the bottom of the tubes. The cycles of PCR were 40 with repeating the following in the order: denaturing temperature of $94^{\circ} \mathrm{C}$ for 20 seconds, annealing temperature of $55^{\circ} \mathrm{C}$ for 30 seconds, and extension temperature of $72^{\circ} \mathrm{C}$ for $1 \mathrm{~min}$. The final extension was performed at $72^{\circ} \mathrm{C}$ for $5 \mathrm{~min}$ and then cooled down to $4^{\circ} \mathrm{C}$.

The reaction products were analyzed by gel electrophoresis in $1.5 \%$ agarose gel $(100 \mathrm{~V}, 60 \mathrm{~min})$ and visualized by ethidium bromide staining. The bands were identified using the image analysis system (Chemi Doc XRS, Bio-Rad, USA).

\section{Elution and sequence determination of SEMG} gene

The PCR products were purified through the agarose gel electrophoresis according to the manufacturer (AccuPrep ${ }^{\circledR}$ PCR/Gel Purification Kit, Bioneer Corporation, Korea). The PCR products were subjected to the electrophoresis and stained with ethidium bromide. The visualized gel bands were cut out using blade. The gel slices were mixed with 3 volumes of FB buffer. The tubes were incubated at $50^{\circ} \mathrm{C}$ for $10 \mathrm{~min}$ with mixing by inverting every $2-3 \mathrm{~min}$ One volume of absolute isopropanol was added and mixed immediately by inverting. The mixture was transferred to a binding column in a $2 \mathrm{~mL}$ collection tube. The lid was closed and spun at 14,000 rpm for $1 \mathrm{~min}$. The binding column was reassembled with collection tube after removing the flow-through fluid. $500 \mu \mathrm{L}$ of W2 buffer was added and spun at 14,000 rpm for $1 \mathrm{~min}$. The binding column was reassembled like above. Then the step with W2 buffer was repeated once more and spun at 14,000 rpm for $1 \mathrm{~min}$. The binding column tube was transferred to a new $1.5 \mathrm{~mL}$ tube for elution. $30 \mu \mathrm{L}$ of EA buffer was added carefully onto the binding column tube and waited for at least $1 \mathrm{~min}$ at room temperature. Finally the new tube was spun at 14,000 rpm for $1 \mathrm{~min}$. The eluant was sent to Bioneer (Korea) to analyze the sequence of SEMG gene.

\section{RESULTS}

1. Expressions of SEMG gene in reproductively active animals

The male Syrian hamsters housed in LP for 8 weeks showed large testes that was $1.4 \mathrm{~g}$ of average of each testis, which represents full spermatogenesis. The expression of SEMG gene was primarily detected in the seminal vesicles of male Syrian hamsters (Fig. 1). The size of the SEMG gene sequenced was $308 \mathrm{bp}$, which is $6 \mathrm{bp}$ longer than expected (Fig. 2). The seminal vesicles of males obviously showed the expression of SEMG. GAPDH was used as reference standard for RT-PCRs. 


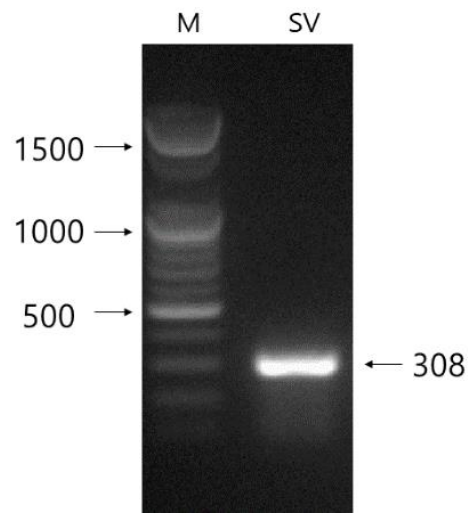

Fig. 1. The RT-PCR result of SEMG gene. Seminal vesicle of Syrian hamster was subjected to the RTPCR. M; 100 bp marker. SV; seminal vesicle; RT$\mathrm{PCR}$, reverse transcription polymerase chain reaction; SEMG, semenogelin.

\section{Comparison of the SEMG mRNA}

The mRNA of SEMG gene of Syrian hamster that identified in this investigation was compared to other SEMG genes of chinese hamster, rat, and mouse reported in the range of sequence detected (308 bp, Fig. 2). The sequence of SEMG of the Syrian hamster had homology of 94.8\% to the predicted sequence of Chinese hamster (Cricetulus griseus) SEMG1 mRNA (XM_003504573.1), 85.1\% to Rattus norvegicus SEMG1 mRNA (NM_012710.2), and $84.4 \%$ to mouse (NM_017390.4). A point to be worth noticing is that there are gaps between the nucleic acid sequence of SEMG gene of Syrian hamsters and those of other rodents. Particularly, there were gaps of 3 places in the comparison to the chinese hamster. In the matching of the sequence of SEMG gene of Syrian hamsters to that of other animals in order to attain the best correspondence, there were discrete gaps of several places.

\section{No expression of SEMG gene in sexually regressed} testis

In order to inspect the relationship of SEMG and fertility ability in male Syrian hamsters, the expression of SEMG gene was investigated in the two functionally different testes: reproductively energetic testes and completely regressed testes of the Syrian hamsters maintained in LP and SP, respectively. The Syrian hamsters housed in LP had large testes of $2.1 \pm 0.03 \mathrm{~g}$ of mean weights of testes and the animals maintained in SP for 8 weeks showed very small testes of $0.4 \pm 0.02 \mathrm{~g}$ of mean weights of testes. The representative mass of testis in each photoperiod was shown in Fig. 3A. In the histological view of testes, LP animals had all kinds of germ cells but SP animals primarily spermatogonia and some spermatocytes (Fig. 3B). The seminal vesicles also showed similar aspects in which LP hamsters demonstrated relatively bigger and heavier seminal vesicles than those of SP animals $(0.8 \pm 0.01 \mathrm{~g}$ in LP vs $0.3 \pm 0.03 \mathrm{~g}$ in SP, Fig. $3 \mathrm{C}$ ). The LP animals had abundant spermatozoa in testis but the SP animals showed no spermatozoa at all in the organ tissue (Fig. 3D).

The expression of SEMG gene was witnessed in the seminal vesicles of the reproductively active Syrian hamsters kept in LP (Fig. 1). The gene was not detected in the SP-induced small testes, which is an indicative of cessation of spermatogenesis to be ended (Fig. 3E).

\section{Expressions of SEMG gene in the course of SP}

The expression of SEMG gene was examined in the seminal vesicles from the period of time after maintaining the Syrian hamsters in SP. During the course of SP they were subjected to RT-PCR at the indicated time points. The expressions of the gene in the seminal vesicles were shown in Fig. 4. The SEMG mRNA was detected at the third week of SP, blurred at the sixth week of SP, and ultimately vanished at eighth week at which this experiment was planned to be ended. The results were compatible with the fertile ability of male Syrian hamsters housed in SP.

\section{DISCUSSION}

The present results represent the correlation of the SEMG gene with the fertility capability in male Syrian 
S. H. 1 tggccaacaa aaatccctga aaggtttctc tcaacaaact cagaataaag

C. H.

rat

mouse

S. H. 51

C. H.

rat

mouse

S. H. 101

C. H.

rat

mouse

S. H. 151

C. H.

rat

mouse

S. H. 201

C. H.

rat

mouse tggccaacaa aaatccctaa aaggtttctc tcaacaaact cagcataaag tggccaacaa aaatccctca aagggttttc tcaacaaact caacagaaag tggccaacaa aaatccctca aaggtttttc tcaacaaact cagcataaag

gatttgctat gaatgaggaa ctatcacaag tgcgtaaaca gtatgatgaa gattgctat gaatgaagaa ctatcacaag tgcgcaaaca atatgatgaa gat tgccat ggatgaagat ttgtcacaag tgcggaaaca att gacgat gatttgccat ggatgaaggt atgtcacaag tgcggaaaca att $t-a-g-t$

gacgatgacc agtctgtgca acaaaagtct agccaacagg taaaaacaga gatgatgacc agtctgtaca acaaaagtct agccaacagg taaaaacagg ga---tgacc tctctgtaca acagaagtct acccaacaga tgaaaacaga gacgatgacc tctcagtaca acagaagtct acccaacaga tgaaaacaga

ggaagacttg tcccagtttg gacaacaacg ccaatttgga caagaacgct ggaagact + - --acaatttg gacaacaacg ccaatttgga caagaacact ggaagact ta tcccaatttg gacaacaacg acaatttgga caagaacgct ggaagactta tcccaattcg gacaacagcg gcaatatgga -aagagcgct

cacaatccta taaaggatat ct gaacaat acaaaaagaa atcacaagac cacaatccta taaaggatat cttgaacaat acaaaaagaa atcacaagac cccaatccta taaaggatat cttgcacaat acagaaagaa attacaggaa cacaatccta taaaggatat cttgagcaat acagaaagaa agtacaagaa

S. H. 251 cactatcaac aaagaagaga ttttaatcaa gatagctatt ttacaaaggg

C. H. cactatcaac aaagaaaaga $\mathrm{ttttaatcaa} \mathrm{gatggctatt} \mathrm{ttacaaaggg}$ rat caacaacaac --agaa-aaa ttttaatcag gataacttt t tacaaaggg mouse caa---caac gaa-aa-a-a ttttaatccc ggtaactatt ttacaaaggg

G. H. $301 \quad$ aggggcag

C. H. aggggcag

rat aggggcag

mouse aggagcag

Fig. 2. Comparison of the nucleic acid sequence of Syrian hamster SEMG gene in some mammals. S. H., Syrian hamster; C. H., Chinese hamster; SEMG, semenogelin. 


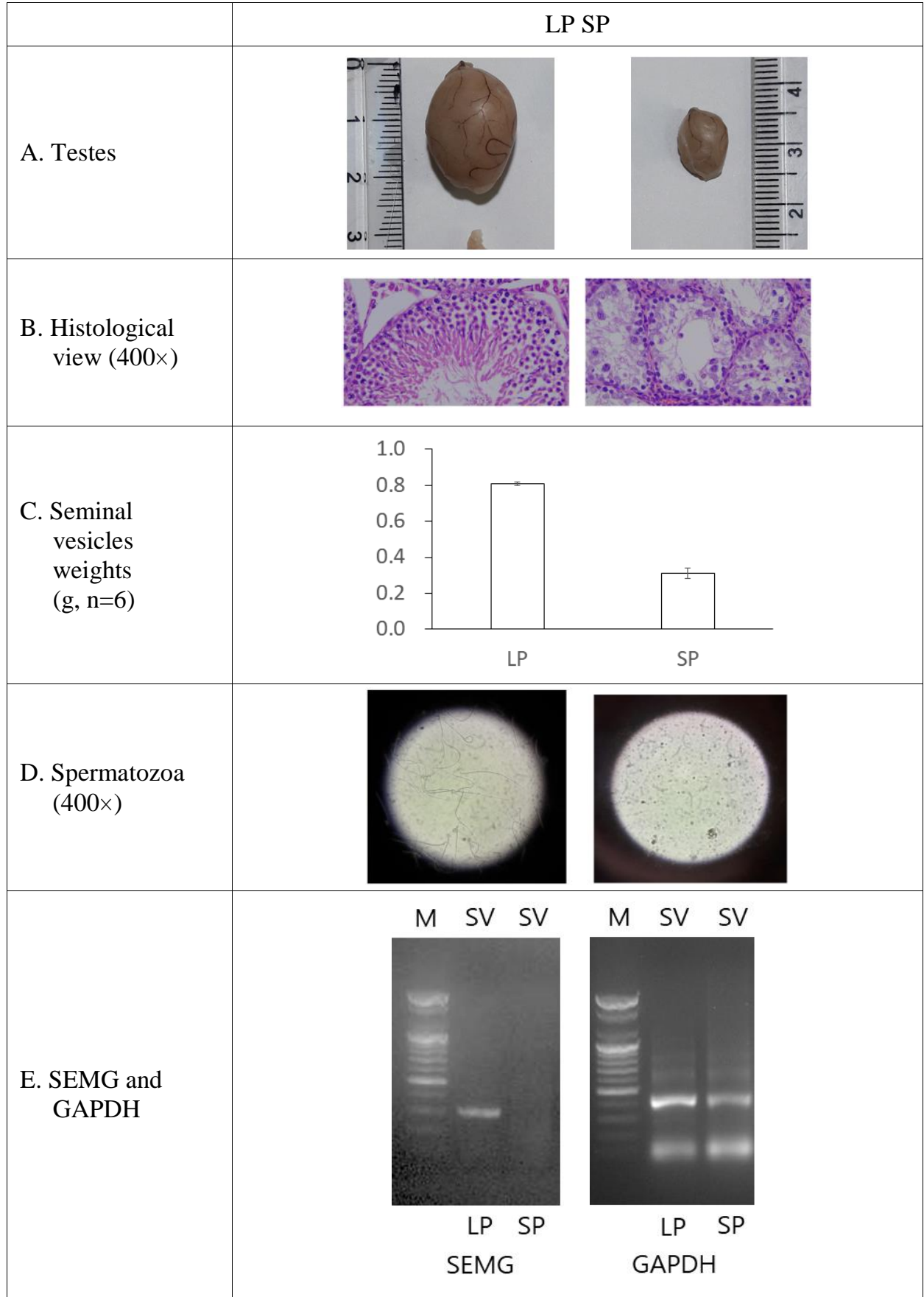

Fig. 3. Representative testicular mass (A), histological view of testis (B), seminal vesicles' weight (C), the presence and absence of spermatozoa (D), and representative RT-PCR products of SEMG gene (E) in the sexually matured (LP) and completely regressed (SP) male Syrian hamsters. LP animals showed big testes and SP animals small ones (A). LP animals had all kinds of germ cells but SP animals primarily spermatogonia and some spermatocytes (B). The seminal vesicles also showed similar aspects of weights as the testicular weights in each photoperiod $(\mathrm{C})$. The spermatozoa were observed plentifully in LP animals with entirely absence of those in SP animals $(\mathrm{D}, \times 400)$. SEMG genes were not detected in the seminal vesicles of SP animals at all (E). M; $100 \mathrm{bp}$ marker. SP, short photoperiod; LP, long photoperiod; SEMG, semenogelin; GAPDH, Glyceraldehydes-3-phosphate dehydrogenase; SV, seminal vesicles; RT-PCR, reverse transcription polymerase chain reaction. 


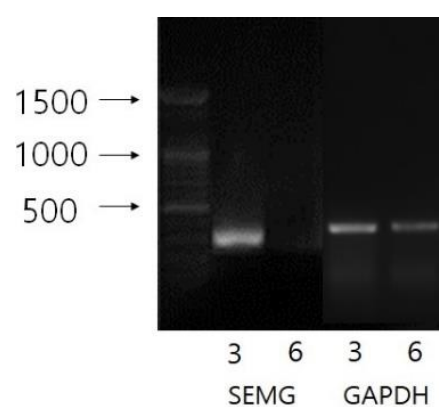

Fig. 4. The representative RT-PCR products of SEMG gene in the Syrian hamsters housed in SP. The expressions of SEMG gene in the seminal vesicles of male Syrian hamsters were examined at 3rd and 6th weeks after exposure to SP. RT-PCR, reverse transcription polymerase chain reaction; SEMG, semenogelin; SP, short photoperiod.

hamsters. Only reproductively active Syrian hamsters expressed SEMG genes in seminal vesicles. In the sexually regressed testis of SP animals, SEMG mRNA was not detected in seminal vesicles. And the sharply reduced detection of SEMG mRNA was emerged at the 6th week in the male Syrian hamsters housed in SP. This is the first report that the expression of SEMG gene is directly correlated to the fertility competence in these animals.

The Syrian hamsters exhibit completely regressed testes in 8 weeks of SP in laboratory facility (Stetson \& WatsonWhitmyre, 1984; Stetson \& Watson-Whitmyre, 1986). The degenerated testes are confirmed by relatively shortened diameter of more than one half of seminiferous tubule (nearly one eighth in volume), indicating the absence of germ cells experiencing meiosis (spermatozoa, spermatid, and spermatocytes) in the histological examination (Choi, 2013).

In the present research, the SEMG gene was expressed in seminal vesicles of the sexually active male Syrian hamster. These results were previousy observed and some other tissues were also reported to express the gene (Lundwall et al., 2002). They described SEMG as the predominant human seminal plasma proteins to be expressed in nongenital tissues, meaning other funtions unknown so far.
When the SEMG gene identified in male Syrian hamster was compared to the genes of other species (Fig. 2), it had very high proportion of homology, impling the same function mentioned in other reports (Richardson et al., 2001; Sivashanmugam et al., 2003). The sequence of SEMG gene of the Syrian hamster identified in this investigation had broad homology to that of other rodents (94.8\% to Chinese hamster, $85.1 \%$ to rat, and $84.8 \%$ to mouse). The comparable similarity denotes a possible role reported previously.

The SEMG protein provides a basis to reduce spermatozoa motility, leading to prevention of the spermatozoa to fertilize the egg (O'Rand et al., 2011; O'Rand et al., 2016; O'Rand et al., 2018). The antibody to the SEMG protein also raise a possibility as a contraceptive by inhibiting the action of the subsequent protein in the pathway of the spermatozoa to gain fertilization capability (O'rand et al., 2004). Thus the gene product presents a notable site to develop an anticonceptive agent.

In the male Syrian hamsters whose sexual activity was completely arrested by SP, the SEMG gene was not expressed in seminal vesicles. The distinguished regression was assured by the reduced size, lowered weights of testes, and the absence of spermatozoa (Choi \& Lee, 2012). Accordingly, the results demonstrate that the SEMG gene could be a possible (semen) biomarker because the gene is exclusively expressed in the reproductively energetic animals (Suttipasit \& Wongwittayapanich 2018).

On the other hand, the function of SEMG protein mentioned above raises a reasonable possibility that a natural product would exert as a contraceptive agent if it binds to the SEMG protein on the surface of spermatozoa. SEMG protein can be bound by another protein SEMG, which provide a reaction site for PSA, resulting in the increase of spermatozoa motility. By the binding of a natural product to the SEMG, if SEMG can not bind to the SEMG and PSA is unable to recognize the SEMG-SEMG complex, the capability of the spermatozoa to fertilize the 
egg will be sharply reduced. The incapability will be appeared by increase of viscosity, reduction of motility, and inhibition of action of PSA.

It has not been established when the expression of the SEMG gene is inhibited in the course of SP environment. The expression of SEMG is likely to be diminished at the 6th week of SP. A factor (or factors) that prevent the SEMG gene from expressing in the reproductive organs also has not been known at this time. The inquiry remains to be investigated.

In conclusion, male Syrian hamsters expressed SEMG genes in seminal vesicles. In the reproductively regressed testis of SP animals, SEMG mRNA was not detected, suggesting that the expression of the SEMG gene is associated with fertility capability in male Syrian hamsters. It is a future work when and how the expression of the SEMG gene is controlled in the males housed in SP.

\section{ORCID}

Tae Hong Kim

https://orcid.org/0000-0002-8548-6470

Hyeon Jeong Kim

https://orcid.org/0000-0001-5217-5580

Sung-Ho Lee

https://orcid.org/0000-0003-2866-3642

Yong-Pil Cheon

https://orcid.org/0000-0002-8497-9257

Donchan Choi

https://orcid.org/0000-0002-5170-090X

\section{CONFLICT OF INTEREST}

The authors declare no potential conflict of interest.

\section{ACKNOWLEDGEMENTS}

This research was supported by Basic Science Research Program through the National Research Foundation of Korea (NRF) funded by the Ministry of Education (2017R1 D1A1B03028581).

\section{AUTHOR CONTRIBUTIONS}

Conceptualization: Lee SH, Cheon YP, Choi D.

Data curation: Kim TH, Kim HJ, Choi D.

Formal analysis: Lee SH, Cheon YP, Choi D.

Methodology: Lee SH, Cheon YP, Choi D.

Software: Kim TH, Kim HJ, Choi D.

Validation: Lee SH, Cheon YP, Choi D.

Investigation: Kim TH, Kim HJ. Lee SH, Cheon YP, Choi D. Writing - original draft: Kim TH, Choi D.

Writing - review \& editing: Lee SH, Cheon YP.

\section{ETHICS APPROVAL}

This article requires IRB/IACUC approval because there are animal participants.

This study was approved by Yongin University Institutional Animal Care and Use Committee: YUIACUC-2018-02.

\section{REFERENCES}

Bian ZH, Zhang J, Ding XL, Zhang B, Wang ZJ, Lu CC, Song L, Wang SL, Wang XR (2009) Localization of epididymal protease inhibitor in adult rat and its transcription profile in testis during postnatal development. Asian J Androl 11:731-739.

Bourgeon F, Evrard B, Brillard-Bourdet M, Colleu D, Jégou B, Pineau C (2004) Involvement of semenogelinderived peptides in the antibacterial activity of human seminal plasma. Biol Reprod 70:768-774.

Choi D (2013) Continuous melatonin attenuates the 
regressing activities of short photoperiod in male golden hamsters. Dev Reprod 17:111-119.

Choi D, Han EH (2010) The impacts of photoperiods on hypothalamic proteins in the reproductive activities of golden hamsters. Dev Reprod 14:185-197.

Choi D, Lee SH (2012) Neuroendocrine system in seasonal breeder: Focusing on the reproductive activity of male golden hamster. Dev Reprod 16:1-8.

Cohen DJ, Ellerman DA, Busso D, Morgenfeld MM, Piazza AD, Hayashi M, Young ET, Kasahara M, Cuasnicu PS (2001) Evidence that human epididymal protein ARP plays a role in gamete fusion through complementary sites on the surface of the human egg. Biol Reprod 65:1000-1005.

Dacheux JL, Gatti JL, Dacheux F (2003) Contribution of epididymal secretory proteins for spermatozoa maturation. Microsc Res Tech 61:7-17.

de Lamirande E (2007) Semenogelin, the main protein of the human semen coagulum, regulates sperm function. Semin Thromb Hemost 33:60-68.

du Plessis SS, Gokul S, Agarwal A (2013) Semen hyperviscosity: Causes, consequences, and cures. Front Biosci Elite Ed 5:224-231.

Emami N, Scorilas A, Soosaipillai A, Earle T, Mullen B, Diamandis EP (2009) Association between kallikreinrelated peptidases (KLKs) and macroscopic indicators of semen analysis: Their relation to sperm motility. Biol Chem 390:921-929.

Esfandiari N, Burjaq H, Gotlieb L, Casper RF (2008) Seminal hyperviscosity is associated with poor outcome of in vitro fertilization and embryo transfer: A prospective study. Fertil Steril 90:1739-1743.

Hendry WJ, Weaver BP, Naccarato TR, Khan SA (2006) Differential progression of neonatal diethylstilbestrolinduced disruption of the hamster testis and seminal vesicle. Reprod Toxicol 21:225-240.

Jalkanen J, Kotimäki M, Huhtaniemi I, Poutanen M (2006) Novel epididymal protease inhibitors with Kazal or
WAP family domain. Biochem Biophys Res Commun 349:245-254.

Lundwall A, Bjartell A, Olsson AY, Malm J (2002) Semenogelin I and II, the predominant human seminal plasma proteins, are also expressed in non-genital tissues. Mol Hum Reprod 8:805-810.

Mitra A, Richardson RT, O'Rand MG (2010) Analysis of recombinant human semenogelin as an inhibitor of human sperm motility. Biol Reprod 82:489-496.

Nixon B, MacIntyre DA, Mitchell LA, Gibbs GM, O’Bryan M, Aitken RJ (2006) The identification of mouse sperm-surface associated proteins and characterization of their ability to act as decapacitation factors. Biol Reprod 74:275-287.

O'Rand MG, Hamil KG, Adevai T, Zelinski M (2018) Inhibition of sperm motility in male macaques with EP055, a potential non-hormonal male contraceptive. PLOS ONE 13:e0195953.

O'Rand MG, Silva EJR, Hamil KG (2016) Non-hormonal male contraception: A review and development of an Eppin based contraceptive. Pharmacol Ther 157:105-111.

O'Rand MG, Widgren EE, Beyler S, Richardson RT (2009) Inhibition of human sperm motility by contraceptive anti-Eppin antibodies from infertile male monkeys: Effect on cyclic adenosine monophosphate. Biol Reprod $80: 279-285$

O'Rand MG, Widgren EE, Hamil KG, Silva EJ, Richardson RT (2011) Epididymal protein targets: A brief history of the development of epididymal protease inhibitor as a contraceptive. J Androl 32:698-704.

O'Rand MG, Widgren EE, Sivashanmugam P, Richardson RT, Hall SH, French FS, VandeVoort CA, Ramachandra SG, Ramesh V, Jagannadha Rao A (2004) Reversible immunocontraception in male monkeys immunized with Eppin. Science 306:1189-1190.

O'Rand MG, Widgren EE, Wang Z, Richardson RT (2006) Eppin: An effective target for male contraception. Mol Cell Endocrinol 250:157-162. 
Paasch U, Heidenreich F, Pursche T, Kuhlisch E, Kettner

K, Grunewald S, Kratzsch J, Dittmar G, Glander HJ, Hoflack B, Kriegel TM (2011) Identification of increased amounts of eppin protein complex components in sperm cells of diabetic and obese individuals by difference gel electrophoresis. Mol Cell Proteomics 10:M110.007187.

Richardson RT, Sivashanmugam P, Hall SH, Hamil KG, Moore PA, Ruben SM, French FS, O'Rand M (2001) Cloning and sequencing of human Eppin: A novel family of protease inhibitors expressed in the epididymis and testis. Gene 270:93-102.

Sivashanmugam P, Hall SH, Hamil KG, French FS, O'Rand MG, Richardson RT (2003) Characterization of mouse Eppin and a gene cluster of similar protease inhibitors on mouse chromosome 2. Gene 312:125-134.

Stetson MH, Watson-Whitmyre M (1984) Physiology of the pineal and its hormone melatonin in annual reproduction in rodents. In: Reiter RJ (ed), The Pineal Gland. Raven Press, New York, pp 109-153.

Stetson MH, Watson-Whitmyre M (1986) Effects of exogenous and endogenous melatonin on gonadal function in hamsters. J Neural Transm 21(Suppl):55-80.

Suttipasit P, Wongwittayapanich S (2018) Detection of prostate specific antigen and semenogelin in specimens from female rape victims. J Forensic Leg Med 54:102-
108.

Vidigal DJ, Silva AL, Vasconcelos AC, Fazito DR, Verçosa BL, Santana NG, Vidigal FE (2010) Effect of finasteride on serum prostate-specific antigen (PSA) and on prostate of hamster Mesocricetus auratus (hMa). Acta Cir Bras 25:47-54.

Wu J, Dong X, Liu K, Xia Y, Wang X, Shen O, Ding X, Zhang J (2019) Association of semenogelin (SEMG) gene variants in idiopathic male infertility in ChineseHan population. J Toxicol Environ Health A 82:928-934.

Yamasaki K, Yoshida K, Yoshiike M, Shimada K, Nishiyama H, Takamizawa S, Yanagida K, Iwamoto T (2017) Relationship between Semenogelins bound to human sperm and other semen parameters and pregnancy outcomes. Basic Clin Androl 27:15-22.

Yenugu S, Richardson RT, Sivashanmugam P, Wang Z, O'rand MG, French FS, Hall SH (2004) Antimicrobial activity of human EPPIN, an androgen-regulated, spermbound protein with a whey acidic protein motif. Biol Reprod 71:1484-1490.

Zhang X, Fang J, Xu B, Zhang S, Su S, Song Z, Deng Y, Wang H, Zhao D, Niu X, Wang Z (2013) Correlation of epididymal protease inhibitor and fibronectin in human semen. PLOS ONE 8:e82600. 